Original Article

\title{
Effect of Kelussia odoratissima Mozaff extract on PNPLA3 gene expression in non-alcoholic fatty liver and control rats
}

\author{
Hadis Mohammadi ${ }^{1}{ }^{1}$, Noosha Zia-Jahromi ${ }^{(1 *}{ }^{1 *}$, Abdul Rasul Namjoo ${ }^{2}$
}

\begin{abstract}
Background and Aims: Non-alcoholic fatty liver disease (NAFLD) is associated with such symptoms as steatosis, fibrosis, and liver cirrhosis. Kelussia has attracted assiduous attention due to its protective effects on the liver. The PNPLA3 gene is mainly expressed in the liver and plays a major role in the degradation rate of hepatic triglycerides. Therefore, the present study aimed to assess the effect of Kelussia extract on PNPLA3 gene expression in rats with fatty liver and healthy rats.
\end{abstract}

Materials and Methods: This experimental study was conducted on 24 male Wistar rats in the control group (no treatment), obese group (which received a high-fat diet), treatment group 1 (which received a high-fat diet with Kelussia extract $400 \mathrm{mg} / \mathrm{kg}$ ) and treatment group 2 (a high-fat diet with Kelussia extract $800 \mathrm{mg} / \mathrm{kg}$ ) for six weeks. Blood samples were taken from rats and the factors of (LDL, HDL, Cholesterol, Triglyceride, and fasting sugar) were measured. After sampling the rat liver, the effect of Kelussia on PNPLA3 gene expression was investigated using the Real-time reverse transcription-polymerase chain reaction (RT-PCR) technique and analyzed in SPSS software (version 22).

Results: Based on the results, Kelussia extract at a dose of $800 \mathrm{mg} / \mathrm{kg}$ resulted in a more dramatic decrease in PNPLA3 gene expression in rats with fatty liver, compared to a dose of $400 \mathrm{mg} / \mathrm{kg}$, and this reduction was statistically significant, compared to the fatty liver group $(\mathrm{P}<0.05)$. The results of biochemical tests confirmed liver improvement in the rats treated with Kelussia extract at a dose of $800 \mathrm{mg} / \mathrm{kg}$.

Conclusion: It can be said that Kelussia had a beneficial effect on the reduction of blood lipids; moreover, it reduces the accumulation of triglycerides in the liver and improves the tissue structure of the liver by reducing the expression of PNPLA3 gene; therefore, with more studies, it can be considered a supplement to reduce blood lipids.

Keywords: Kelussia, Non-alcoholic fatty liver, PNPLA3 gene

Citation: Mohammadi H, Zia-Jahromi N, Namjoo AR. [Effect of Kelussia odoratissima Mozaff extract on PNPLA3 gene expression in non-alcoholic fatty liver and control rats]. J Birjand Univ Med Sci. 2021; 28(4): 335-345. [Persian]

DOI http://doi.org/10.32592/JBirjandUnivMedSci.2021.28.4.102

Received: July 12, 2021

Accepted: December 13, 2021

\footnotetext{
${ }^{1}$ Department of Biology, Science Faculty, Shahrekord Branch, Islamic Azad University, Shahrekord, Iran

${ }^{2}$ Department of Pathology, Faculty of Veterinary Medicine, Shahrekord Branch, Islamic Azad University, Shahrekord, Iran

* Corresponding author: Department of Biology, Science Faculty, Shahrekord Branch, Islamic Azad University, Shahrekord, Iran Tel: +989133146504 


\section{بررسى اثر عصاره كرفس كوهى (Kelussia odoratissima Mozaff) بر بيان ثن PNPLA3 در رت هاى مبتلا به كبد هرب غير الكلى و رتهاى سالم}

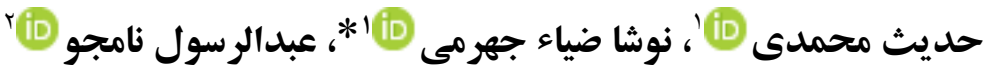

\section{جكيده}

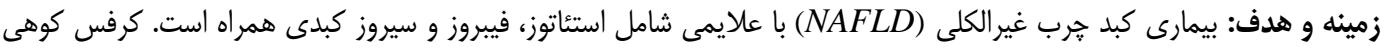

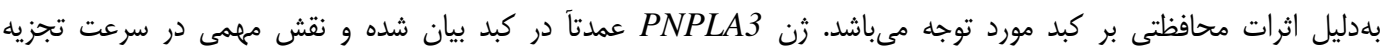

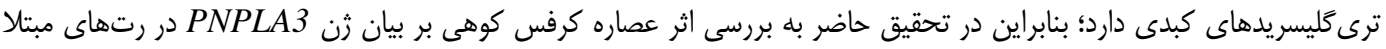

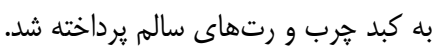

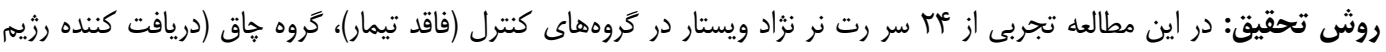

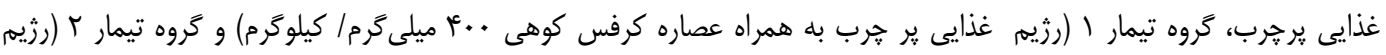

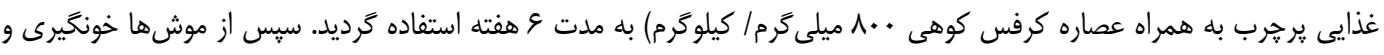

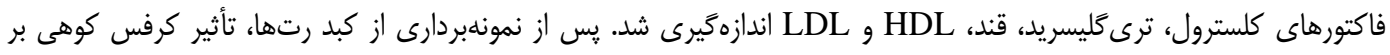

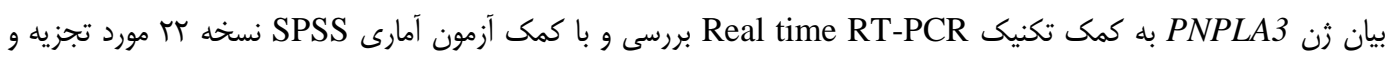
تحليل قرار كرفت.

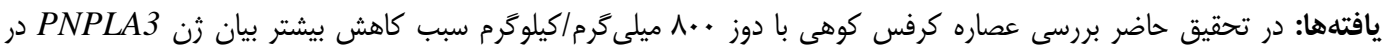

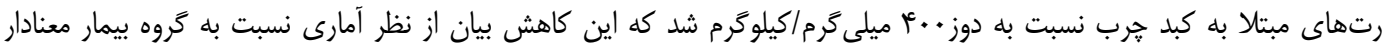

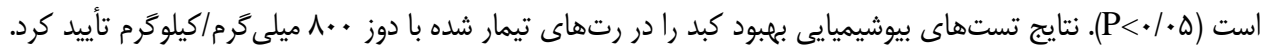

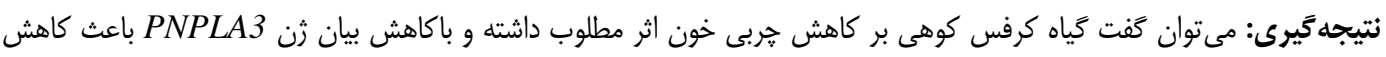

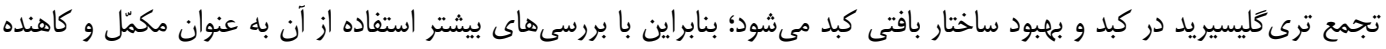

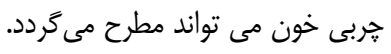
وازههاى كليدى: كرفس كوهى، كبد جرب غير الكلى، PNPLA3

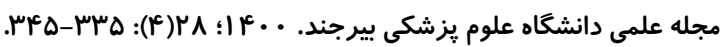

$$
\text { دريافت: |c|r/F/ | }
$$

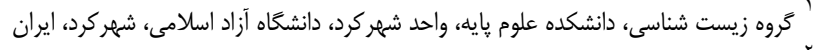

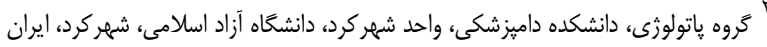
* نويسنده مسئول: كَروه زيست شناسى، دانشكده علوم بايه، واحد شهركرد، دانشكاه آزاد اسلامى، شهركرد، ايران

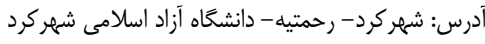

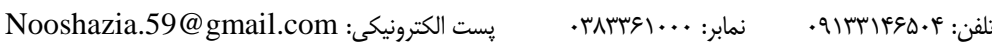


افزايش مى هد و بر اين اساس PNPLA3 از طريق استرين سازى

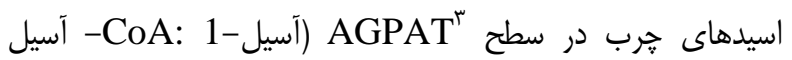
كليسرول-sn3- فسفات استيل ترانسفراز) در داخل بدن نقش لييوزنيك بازى مى كند (سا). فعاليتهاى آن توسط مسيرهاى هورمونى تنظيم رسوب هربى در كبد تنظيم مىشود و همرينين در

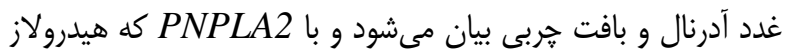
ترى كليسريد اصلى در بافتهاى هربى محيطى است مرتبط است.

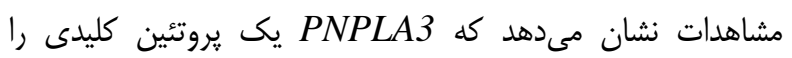

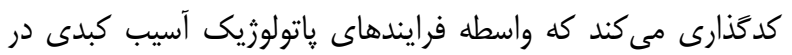

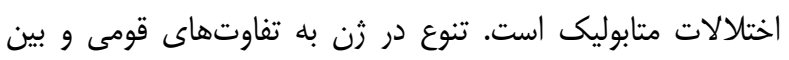
فردى در محتواى خربى كبد و استعداد ابتلا به بيمارى كبد خرب لهاب

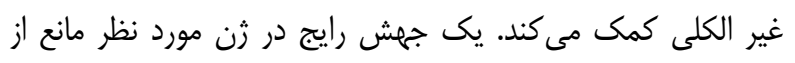

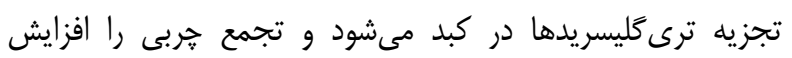
مىدهد (1) مطالعات انجام شده بر روى عصاره تام كياه كرفس كوهى نشان دهنده وجود روتين س و أ و V ترى هيدروكسى فلاونول،

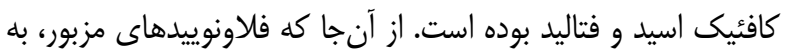

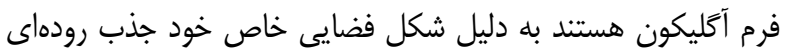

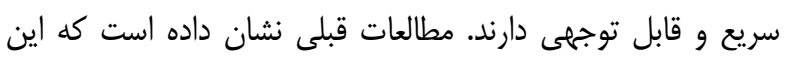

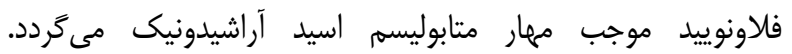

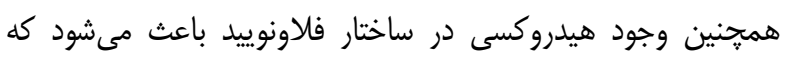

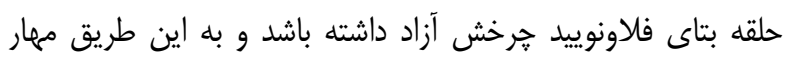

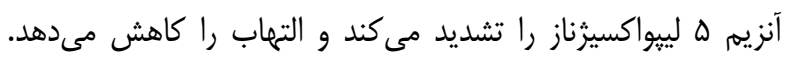
مكانيسم احتمالى اثر فلاونوييدها كه توسط محققان كزارش شده شامل كاهش فعاليت آنزيم استيل كلسترول و آسيل ترانسفراز سلولهاى كبدى، كاهش فعاليت آنزيم هيدروكسى متيل كلوتاتيون

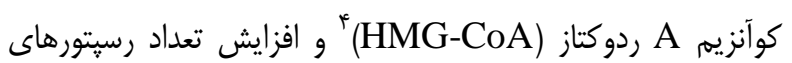

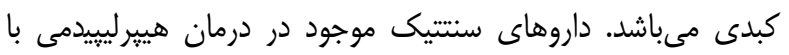

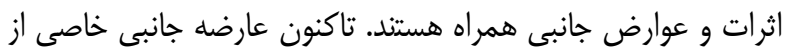

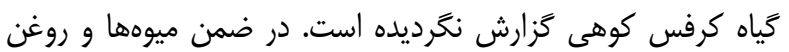
فرار اعضاى اصلى اين خانواده در داروسازى استفاده هاى متعددى درى دردي

${ }^{3}$ Enzyme 1-acylglycerol-3-phosphate-O-acyltransferase ${ }^{4} \beta$-Hydroxy $\beta$-methylglutaryl-CoA
مقلمه

بيمارى كبد هرب غيرالكلى (NAFLD) به صورته جربى در كبد در عدم مصرف بيش از حد الكل تعريف مىشود (().

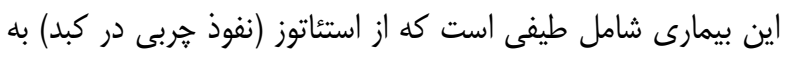

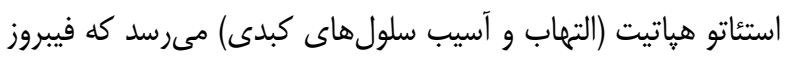

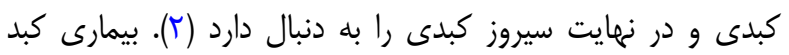
جرب غير الكلى در حال حاضر به عنوان يكى از شايعترين علل بيمارى مزمن كبدى در افراد جوان جامعه در كشورهاى در حال توسعه و توسعه يافته است. تخمين زده شده است كه تا سال •r.r.

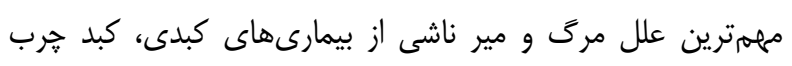

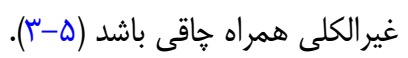
شيوع NAFLD با خندين عامل همجيون سن، جنس، نزاد

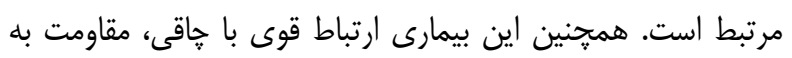

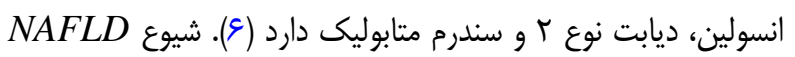

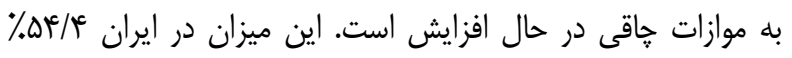

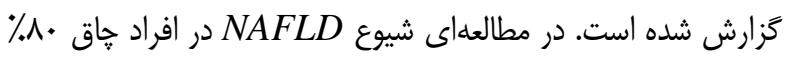
بوده است. در حالى كه اين ميزان در افراد با نمايه توده بدنى نرمال (1'BMI)

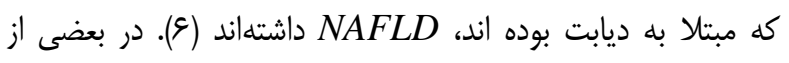
مطالعات بيان شده است كه خطر ابتلا به NAFLD در بين مردان

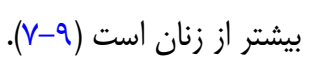

زن مورد مطالعه در اين تحقيق PNPLA3 مى باشد كه توسط است Baulande

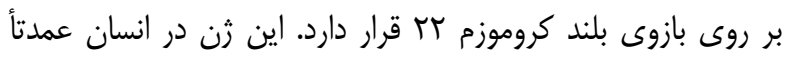

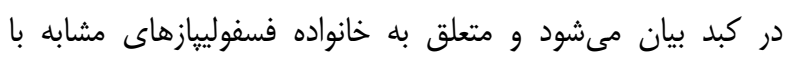

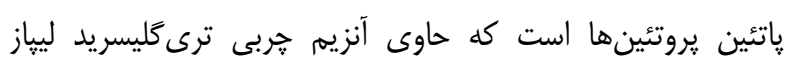

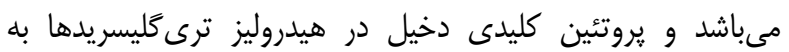

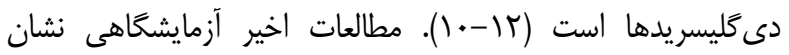

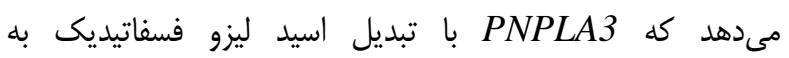
فسفاتيديك اسيد و تجمع هربى در سلولهاى كبدى در حضور اسيد

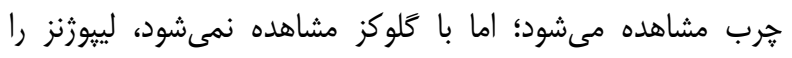

\footnotetext{
${ }^{1}$ Non-alcoholic fatty liver disease

${ }^{2}$ Body mass index
} 
را تشكيل مىدادند. كروه B شامل شش سر رت مبتلا به كبد קرب است كه به عنوان گروه كنترل منفى (كروه دريافت كننده رزيم

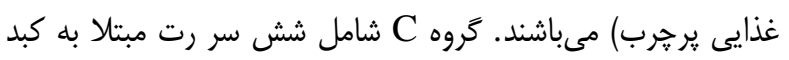

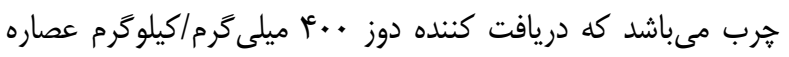

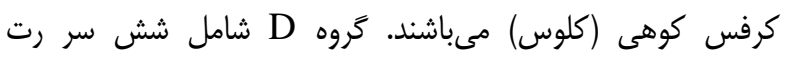

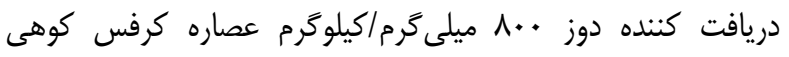

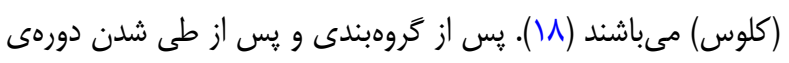

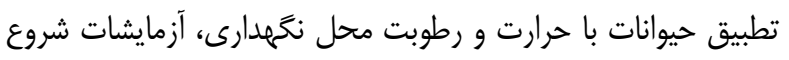

\section{تهيه عصاره كرفس}

در ابتدا كياه كرفس از مناطق كوهستانى مورد نظر استان

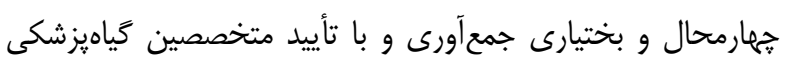

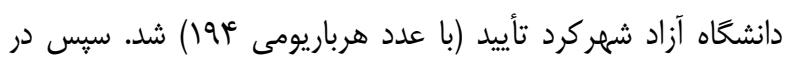

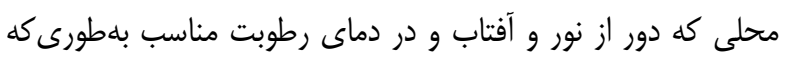

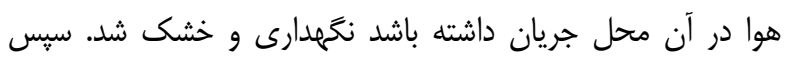
توسط آسياب برقى به قطعات ه/ • تا س سانتى مترى يودر كرده و

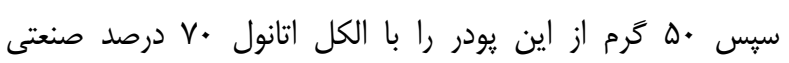

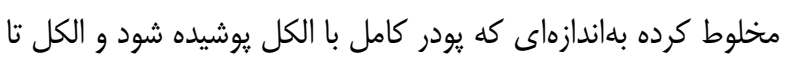

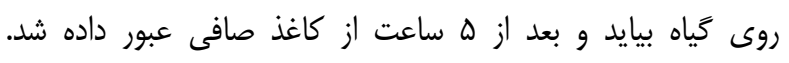
عصارهاى كه پِ از عبور از كاغذ صافى به دست آمد با دستخاه Rotary

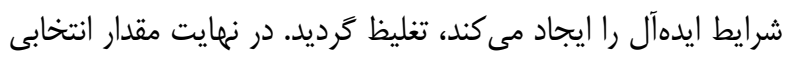

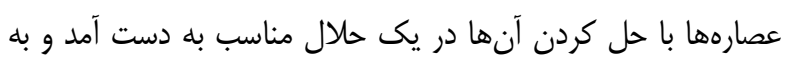

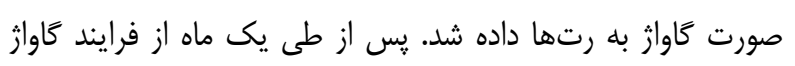

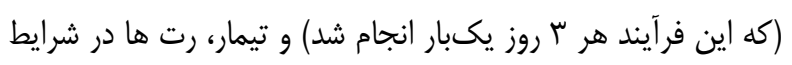

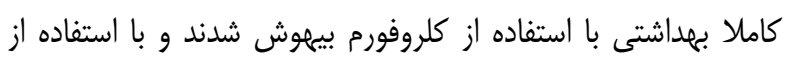
ست جراحى شكم آن ها باز و كبد آن ها برداشته شد.

\section{استخراج RNA و سنتز}

در تحقيق حاضر براى استخراج RNA تام از ترايزول

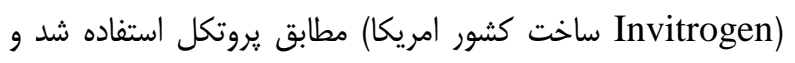

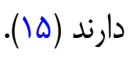

با توجه به آمار فزاينده مبتلا به كبد خرب و همجنين به علت

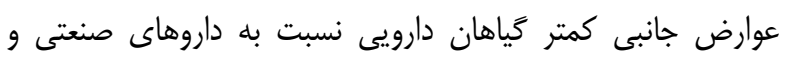

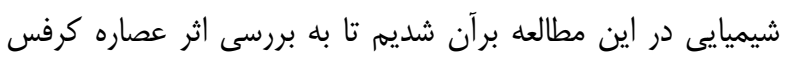

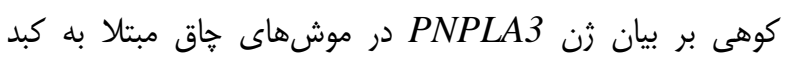

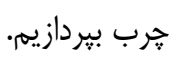

\section{روش تحقيق نوع مطالعه و نمونه}

تحقيق حاضر در كميته اخلاق دانشخاه آزاد اسلامى واحد

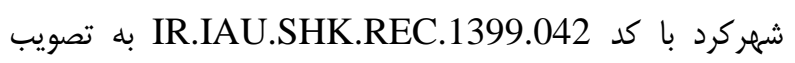
رسيده است. مطالعه حاضر تجربى بود. لازم به ذكر است كه روش

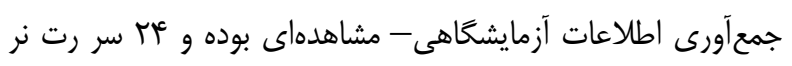

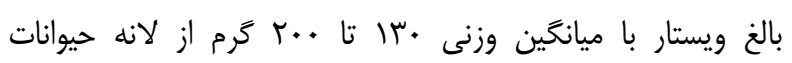
دانشگاه علوم يزشكى شهركرد خريدارى شد و در شرايط استاندارد

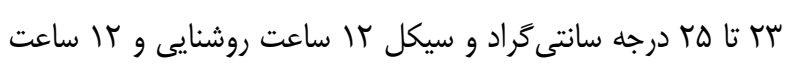
تاريكى با آب و غذاى كافى و استاندارد درون قفس هانى دانى مخصو

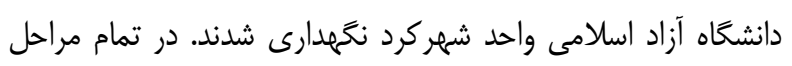

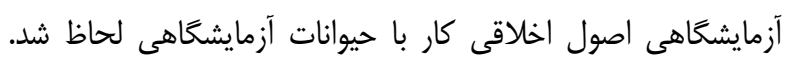

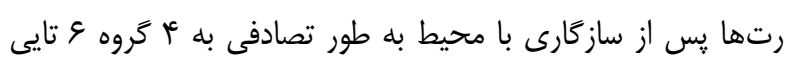

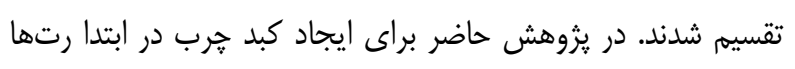

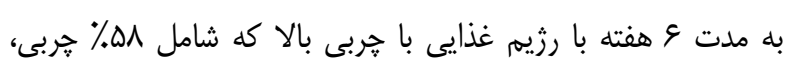

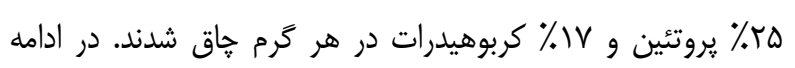

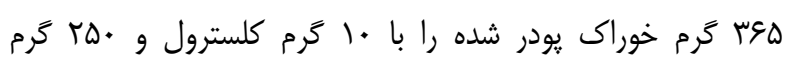

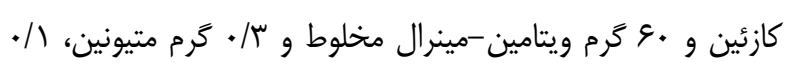

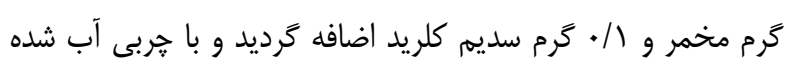

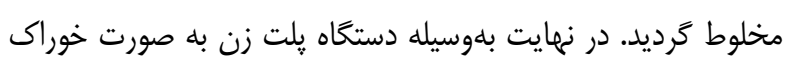

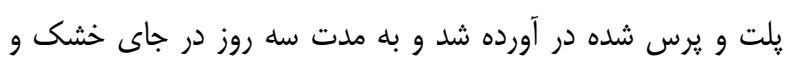

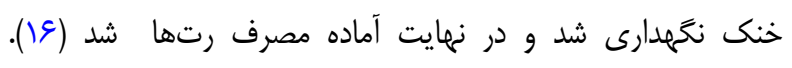

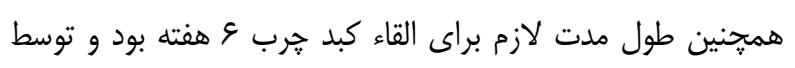

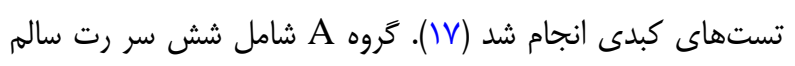

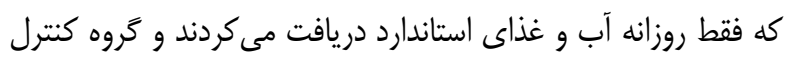


و يرايمر 9 نوكلئوتيدى تصادفى، طبق يروتكل كيت، cDNA هر

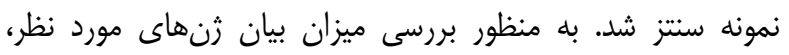

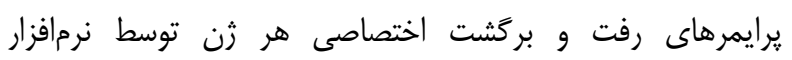
BeaconDesigner 8.0

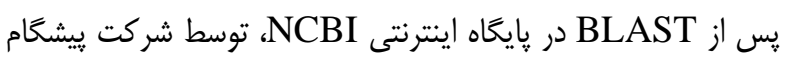
سنتز شد كه در جدول آ آورده شده است.
يس از استخراج RNA استخراج شده از لحاظ كيفى و كمى بررسى

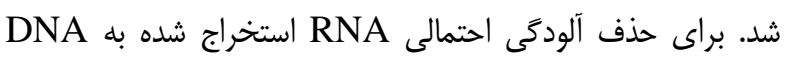

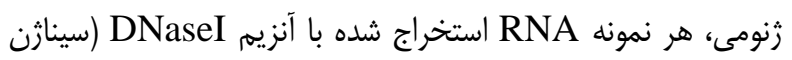

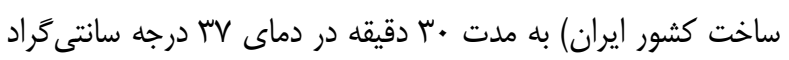

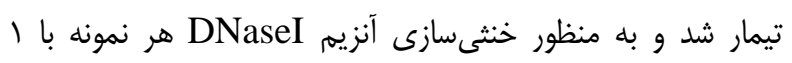

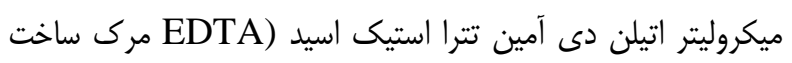

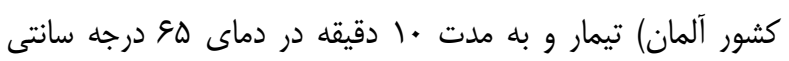

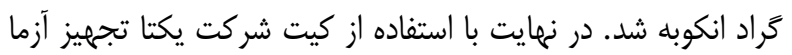

جدول ا- يرايمرهاى مورد نظر

\begin{tabular}{|c|c|c|}
\hline 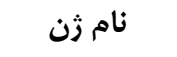 & توالى يرايمر & 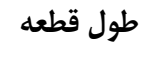 \\
\hline PNPLA3 F & 5'-CAACATTAACAAGTGCGTCAGAG-3' & $109 \mathrm{bp}$ \\
\hline PNPLA3 R & 5'- GCATCCACCACTTCGTCTTTG -3' & \\
\hline GAPDH F & 5'-TGATTCTACCCACGGCAAGTTC -3' & r.. bp \\
\hline GAPDH R & 5'-CGCTCCTGGAAGATGGTGATG -3' & \\
\hline
\end{tabular}

\section{Real time RT-PCR تكنيك}

Real Time -RT PCR در يزوهش حاضر از تكنيك

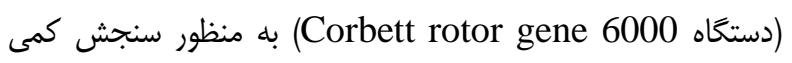
سطح بيان ثنهاى مورد نظر استفاده شد. براى انجام اين تكنيك از SYBR Green در نهايت يس از محاسبه مورد نظر (بيمار) نسبت به نمونه كنترل (سالم) با فرمول $2^{-\Delta C T}$ محاسبه شد.

\section{تست هاى بيوشيميايى}

در اين بررسى تستهاى بيوشيميايى پس إز يايان آخرين تزريق

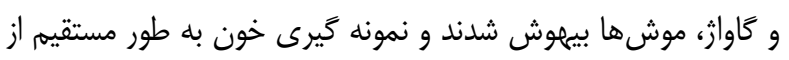
قلب رت ها انجام شد كه شامل تست كلسترول، ترى كليسريد، قند،

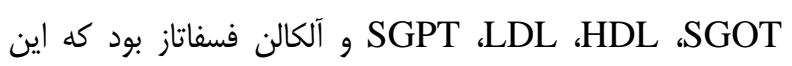
آزمايشات با روش اتوآناليزر و توسط دستخاه اتوآناليزر ( Auto Analyser BT 3000plus

$$
\text { كيت يارس آزمون انجام شد. }
$$

تكنيك RT-PCR

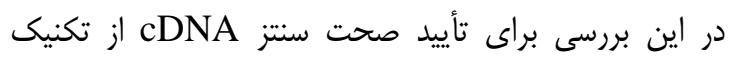

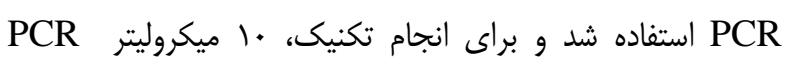
Master Mix

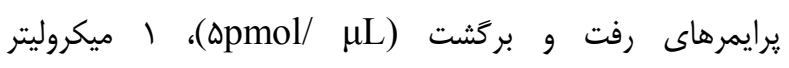

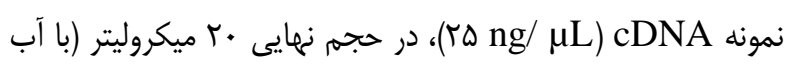

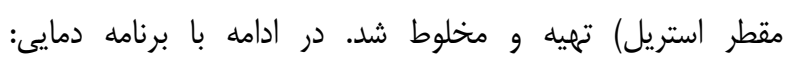

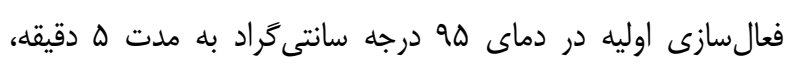

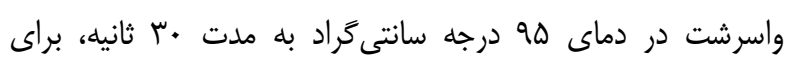

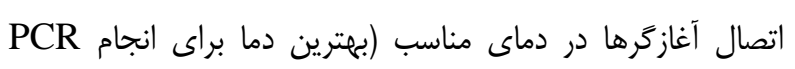

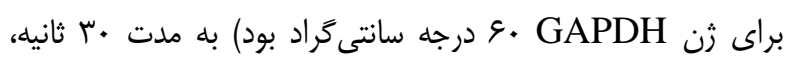
بسط در دماى ץ V درجه سانتى

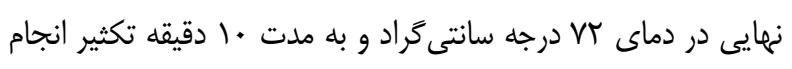

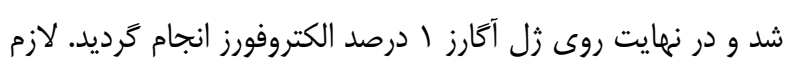

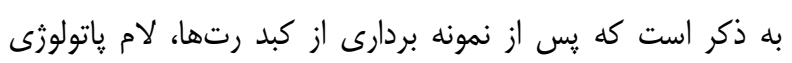
تعيه و نتايج ياتولوزى بررسى شد. 


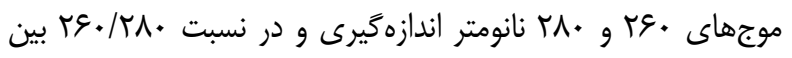

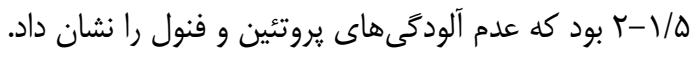

\section{يافته هاى ارزيابى بيان ثن به روش RT-PCR} براى سنتز صحيح CDNA از روش PCR معمولى استفاده شد. در اين روش تمام نمونهها براى GAPDH و ثن PNPLA3،

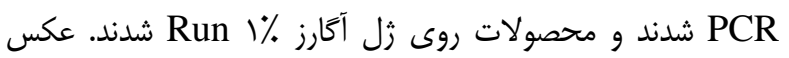
زلها توسط دستخاه UV-Doc گرفته شد. بر اساس نتايج براى زن

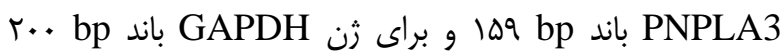
مشاهده شد كه در تصوير ا و r آورده شده است.

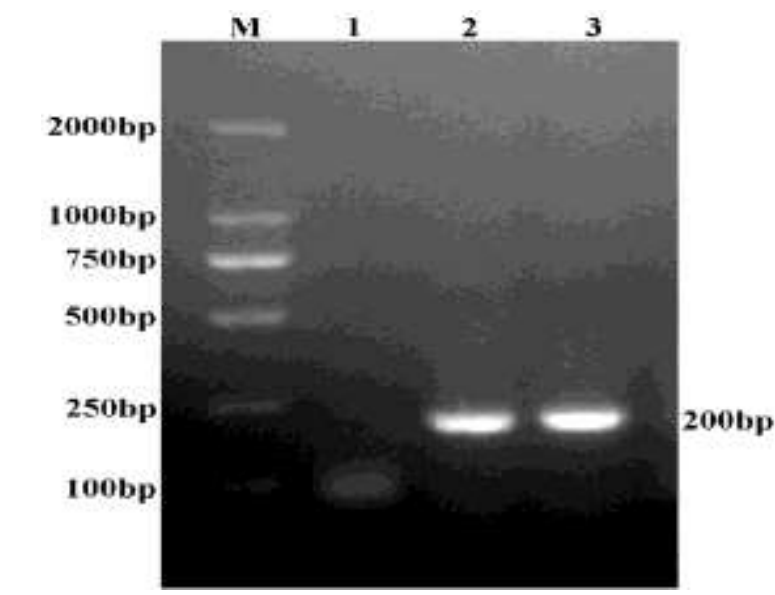

تصوير ا- تأييد صحت سنتز CDNA. جاهك شماره ا كنترل منفى،

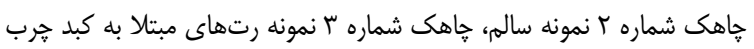

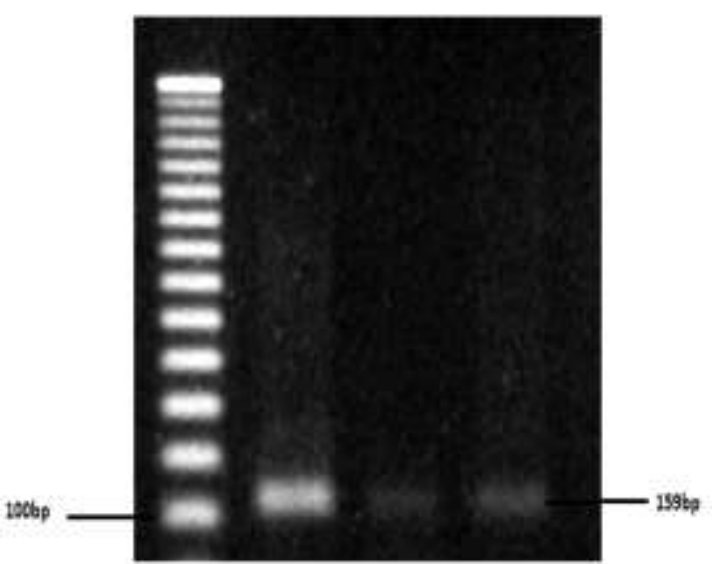

تصوير ץ- تأييد صحت سنتز ثن PNPLA3. جاهى شماره ا ماركر،

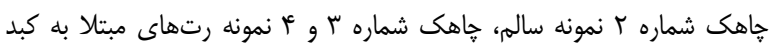

آناليزهاى آمارى

آناليز آمارى با استفاده از نرم افزار SPSS نسخه بم انجام شد. از آنجا كه دادهها از توزيع نرمال برخوردار بودند، با روش آناليز واريانس يك طرفه (ANOVA) و با آزمون تعقيبى LSD ارزيابى شدند و نتايج بصورت Mean I SEM ارائه و تفاوت بين گروههاى مختلف با هـ P P P Pنى دار تلقى شد.

\section{يافتهها}

همانطور كه در نمودار | مشاهده مىشود در زروه كنترل به دليل عدم استفاده از رزيم ڤيرجرب تغييرات وزنى در طول دوره مورد بررسى ناجيز بوده (199) درحالى كه در موشهاى داراى رزيم غذايى يرجرب افزايش قابل توجهى در ميانخَين وزنى موشها يس

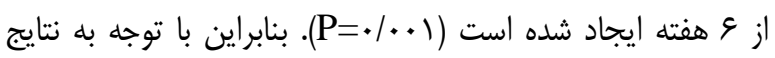
حاصل از بررسى وزن موشها در طول يك دوره 9 هفتهاى يِيش از انجام آزمايشات مىتوان از افزايش وزن موشها و ابتلاى آنها به حاقى اطمينان حاصل نمود.

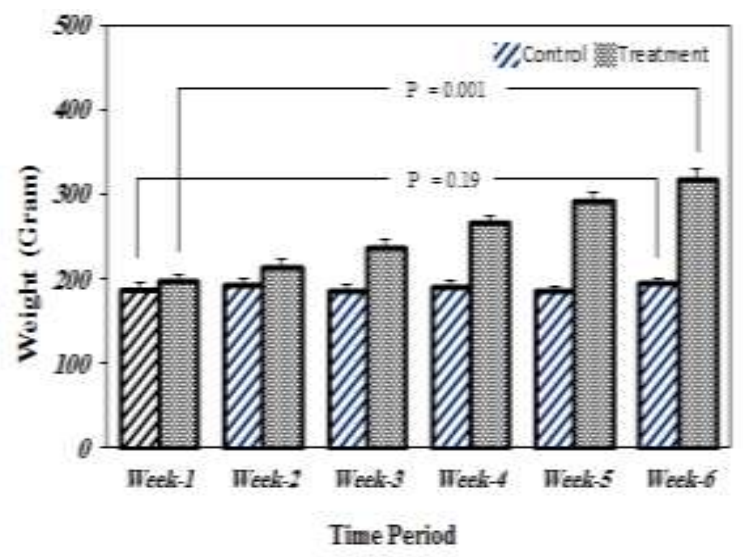

نمودار ا-بررسى تغييرات وزن موش هاى مورد مطالعه در يك دوره

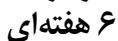

\section{بررسى كمّى و كيفيت RNA استخراج شده بر روى زل}

RNA

باندهاى M S و M S به طور واضح قابل تشخيص بود كه نشان دهنده سالم بودن RNA است. همجنين مقدار ا ميكروليتر از هر نمونه RNA استخراج شده توسط دستخاه نانودراتٍ در طول 
رتهاى مبتلا به كبد حرب را نشان داد. اين عصاره با كاهش بيان

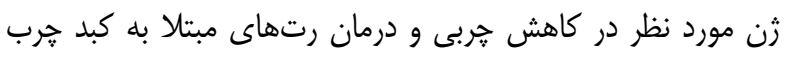
كمى كرد (جدول r).
يافته هاى حاصل از آناليز آمارى

آناليز آمارى دادهها در اين تحقيق كه با استفاده از نرم افزار SPSS نرمال برخوردار بودند. نتايج به دست آمده از اين تحقيق تأثير عصاره

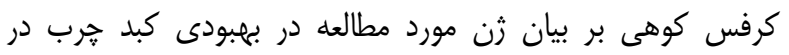

جدول r- مقايسه ميزان تغييرات بيان زن PNPLA3 در تَروه حاق، عصاره كرفس + +f و + +1 نسبت به تَروه سالم

\begin{tabular}{|c|c|c|c|c|}
\hline عصاره كرفس + +1 & عصاره كرفس +. F & جاق & سالم & تحروه \\
\hline $1 / \& \& \pm \cdot /\left.V\right|^{b}$ & $1 / v \Delta \pm \cdot / \sim^{b}$ & $r / V \varepsilon \pm \cdot / r r^{a}$ & $1 / \cdot r \pm \cdot / q^{b}$ & بيان ثن \\
\hline
\end{tabular}

ميانگين ها با حروف لاتين متفاوت اختلاف آمارى معنىدار دارند كه a a , b

\section{نتايج هيستوياتولوزى}

در تحقيق حاضر نتايج هيستوياتولوزى كبد نشان داد كه در

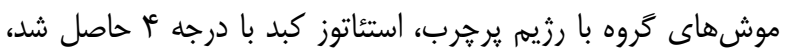

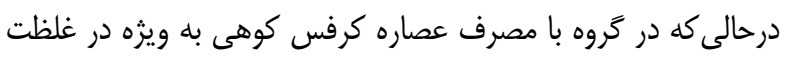

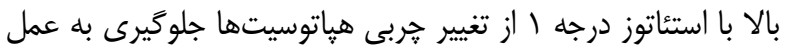
آمده است كه در جدول ب نشان داده شده است. همجنين عكسهای

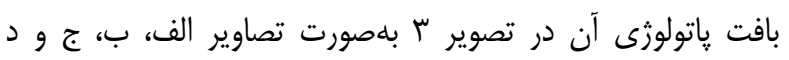
نشان داده شده است.

\section{نتايج تستهاى بيوشيميايى}

طبق نمودار ب مشاهده شد كه ميزان قند خون، ترى كليسريديا كلسترول، LDL در گروه رت مبتلا به كبد هرب درمان شده با دوز

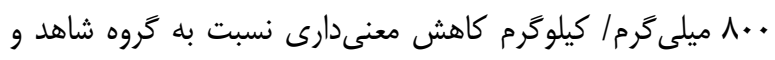

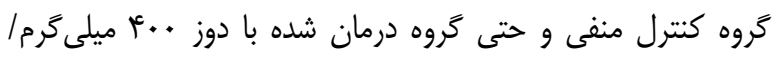

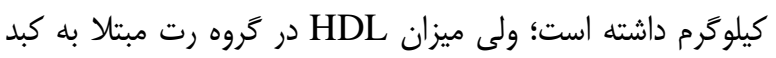

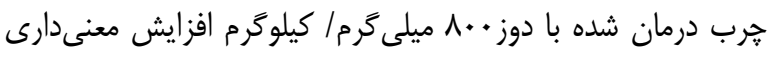

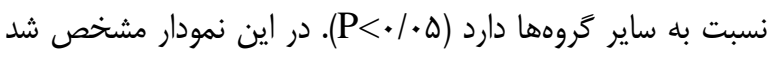
كه در گَروه مبتلا به كبد خرب (گروه كنترل منفى) ميزان

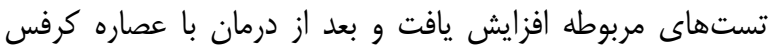

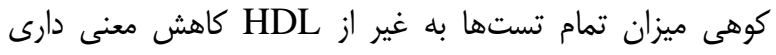

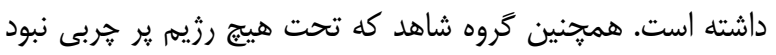
ميزان سالم بودن رتها و عدم داشتن جربى را نشان داد.
گروه كبد هرب غير الكلى به عنوان كنترل ساير گروهها مىباشد

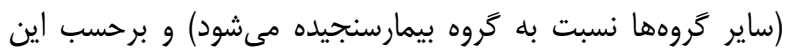

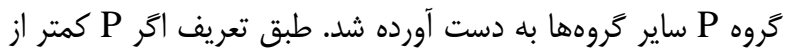

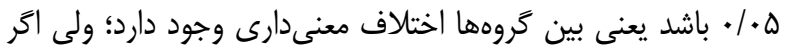

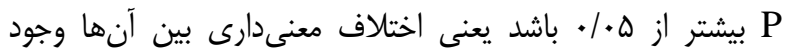

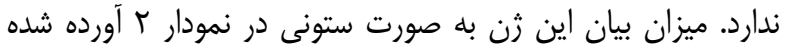

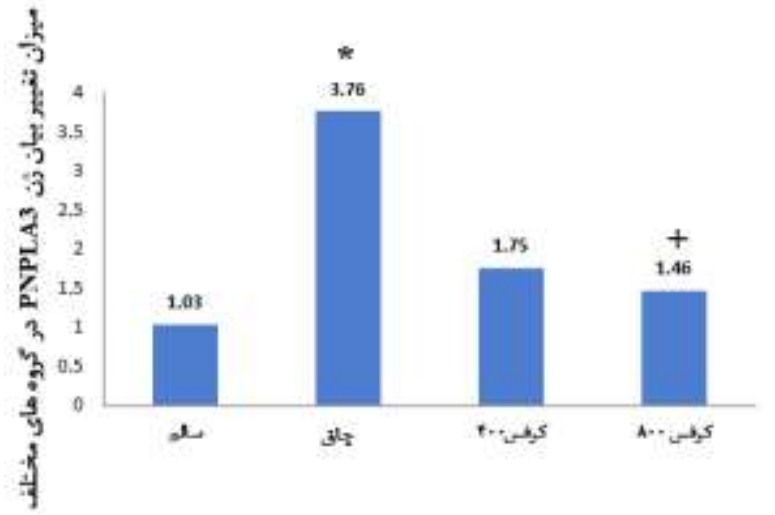
نمودار r- ميزان تغيير بيان زن. بيشترين ميزان بيان مربوط به كروه

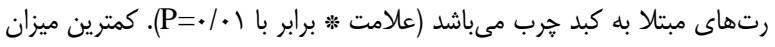

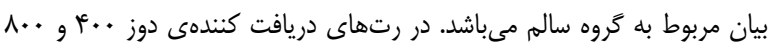

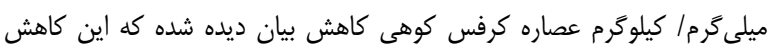
بيان نسبت به كروه هاق معنادار مىباشد (علامت + نشانه كاهش بيشتر است). 


\section{جدول ب- نتايج هيستو پاتولوزى}

\begin{tabular}{|c|c|}
\hline 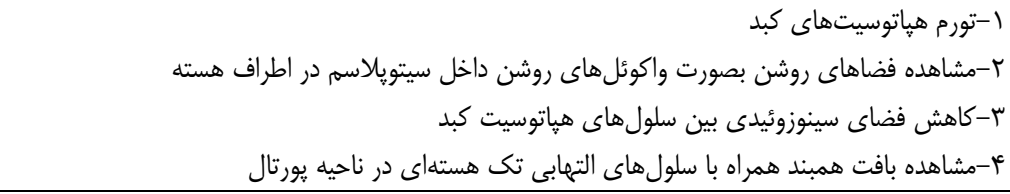 & كبد (كروه بيمار) \\
\hline 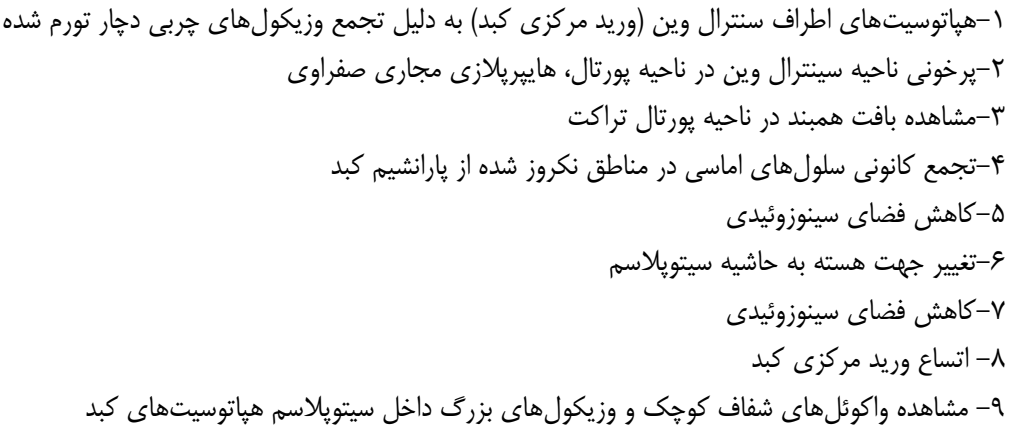 & 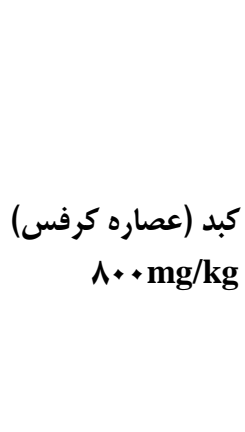 \\
\hline 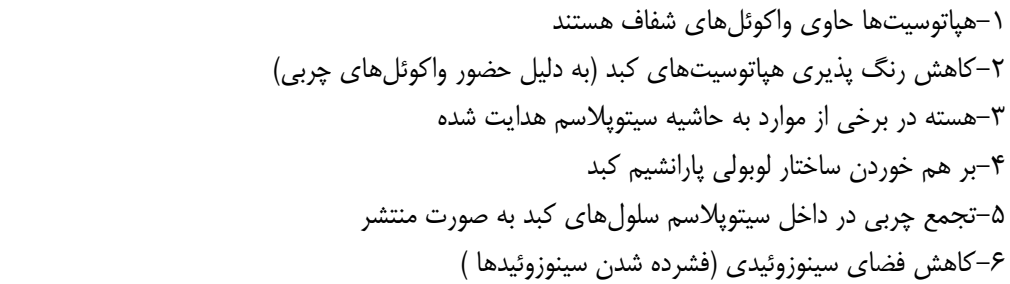 & $\begin{array}{r}\text { كبد(عصاره كرفس) } \\
\text { r + mg/kg }\end{array}$ \\
\hline
\end{tabular}
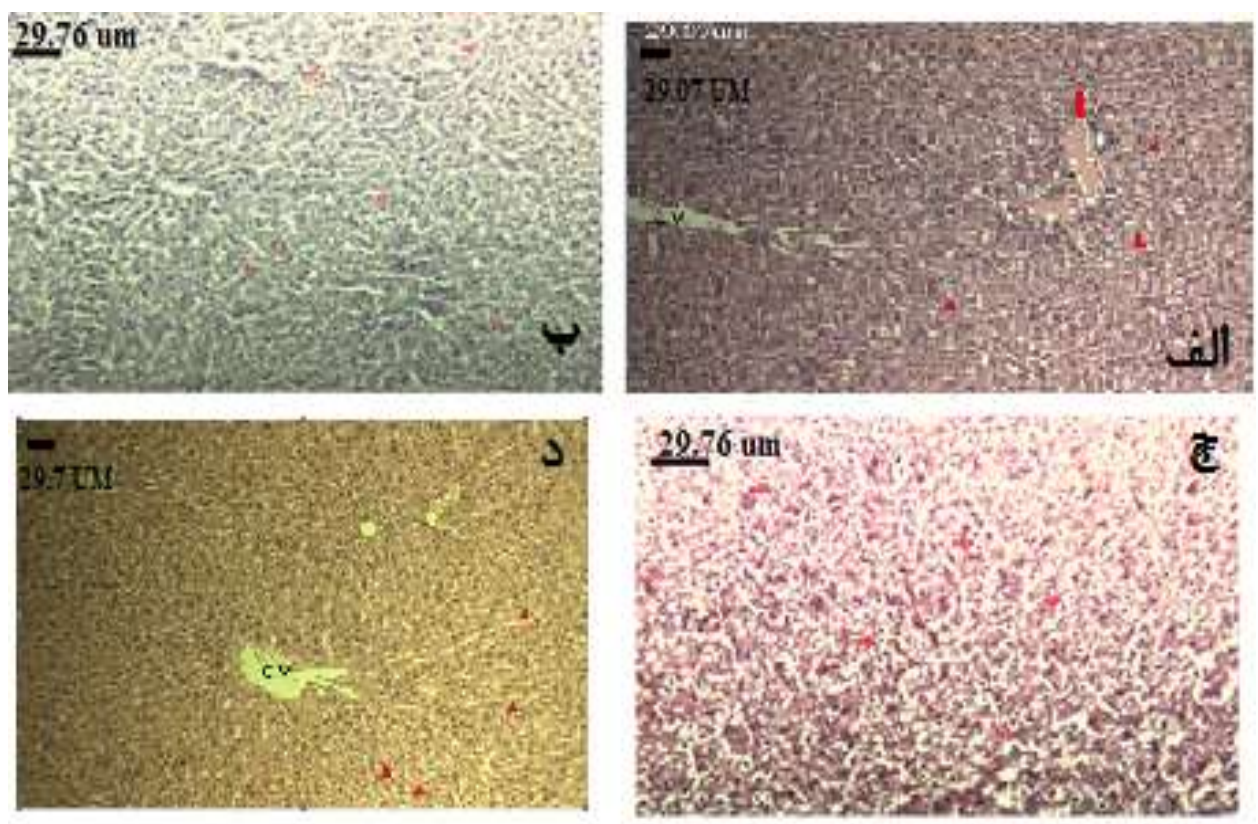

تصوير بـ نتايج هيستوياتولوزى. الف) كبد موش صحرايى، گروه كنترل، هياتوسيتهاى نرمال (سر ييكان قرمز)، ير خونى عروق ناحيه يورتال، و سياهرگ مركزى كبد

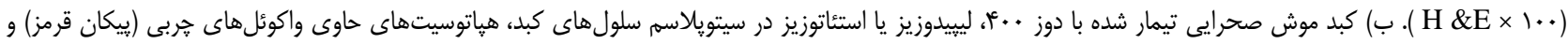

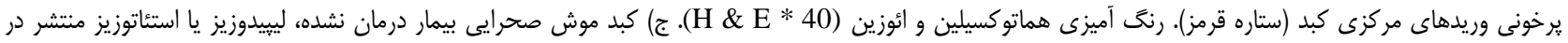

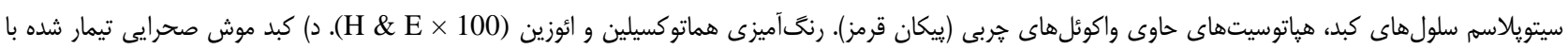

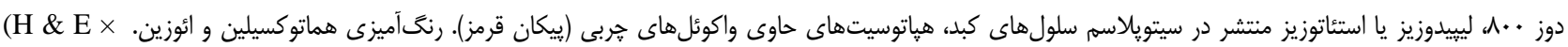


كاهش آسيبهاى يارانشيمى كبد توسط عصاره كياه كلوس، فعاليت

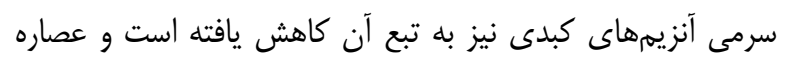

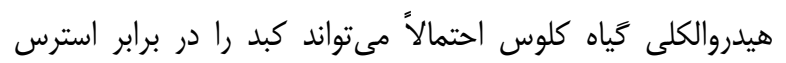

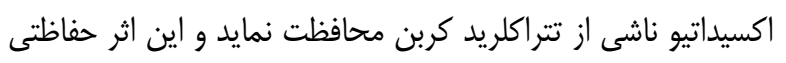

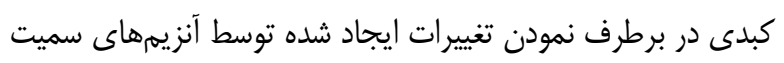

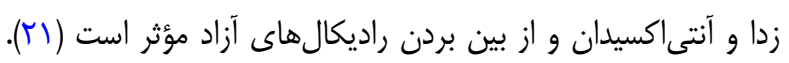

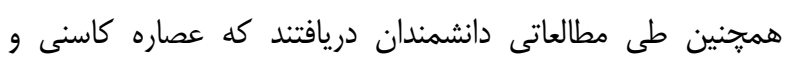

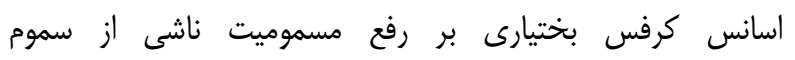

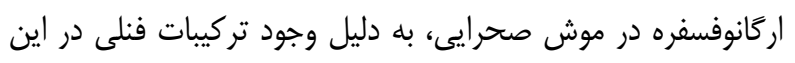

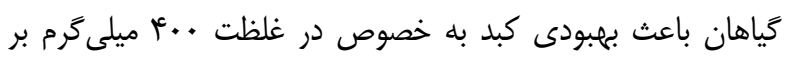
كيلوگرم مى شود (r (ب).

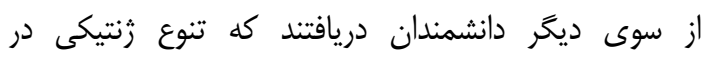
PNPLA3

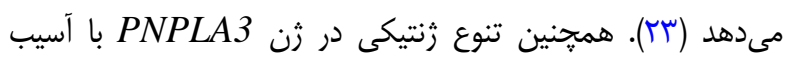
كبدى الكلى همراه است و جهش در زن مهن

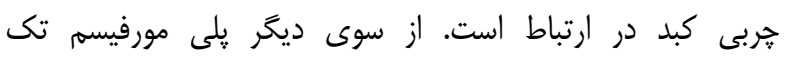
نوكلئوتيدى (M148I) الكلى ييشرفته در افراد وابسته به الكل از نزاد Mestizo همراه

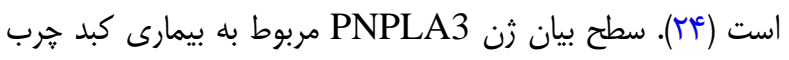

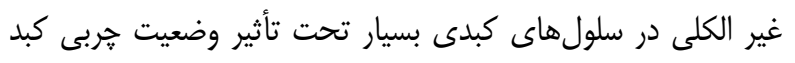
است. مطالعات نشان داده است كه تغييرات در بيمارى كبد جرب غير الكلى (NAFLD) مرتبط است (هڤ). تحقيقات نشان داده است كه ثن PNPLA3 نقش مهمى در بيمارىهاى

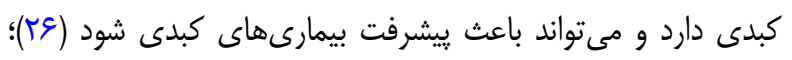
از سوى ديگر بررسى بيان زن

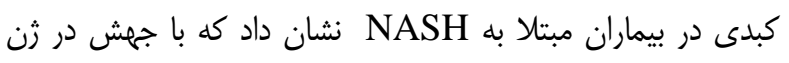
PNPLA3

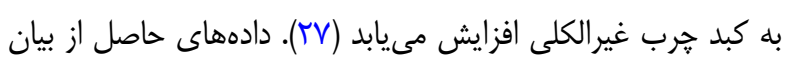

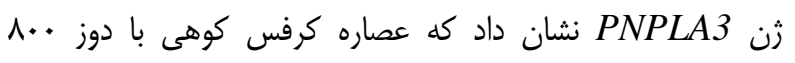

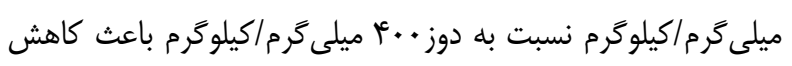

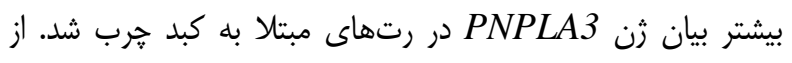

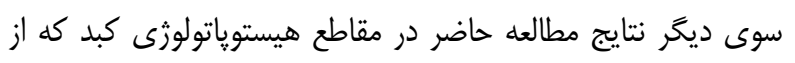
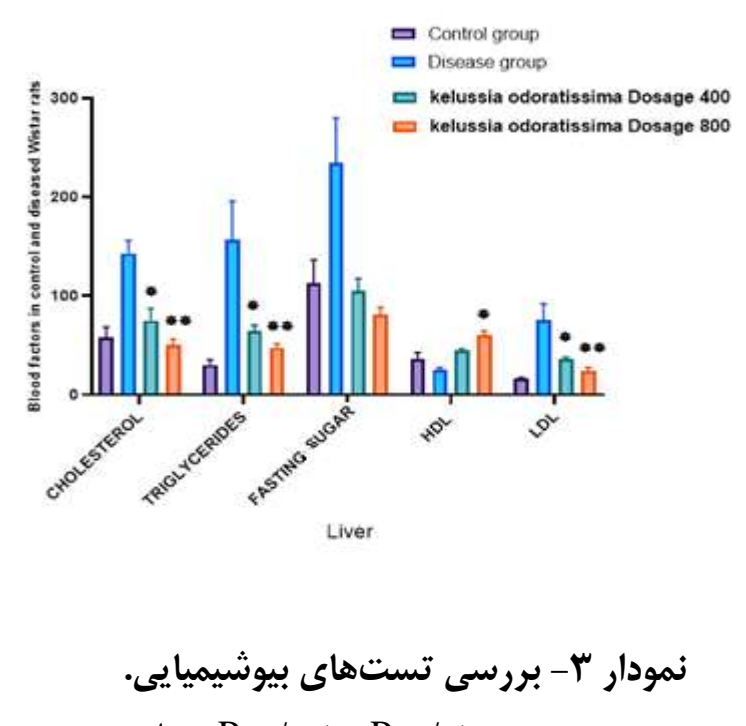

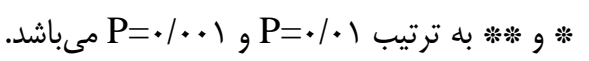

امروزه رويكرد مردم نسبت به استفاده از گياهان دارويى به علت عوارض ناشى از مصرف داروهاى شيميايى افزايش يافته است. از

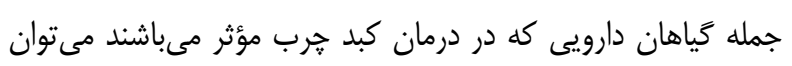

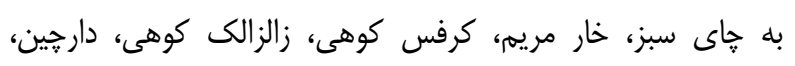

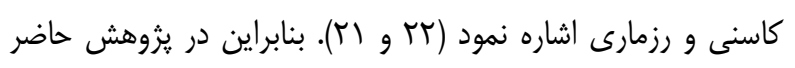
به بررسى اثر عصاره كرفس كوهى (كلوس) بر بيان ثن

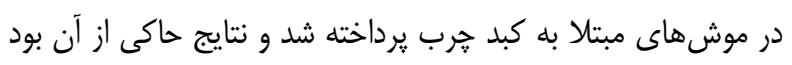

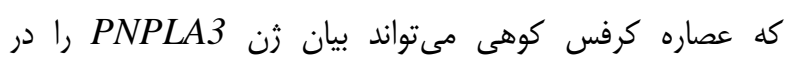
موشهاى مبتلا به كبد هرب افزايش دهد. براى ارزيابى نتايج اين كاين يزوهش بررسىهايى انجام شده است كه در ادامه به توضيح معمترين آنها يرداخته شده است. بررسى ها نشان داده است كه خاصيت آنتىاكسيدانى گياهان به

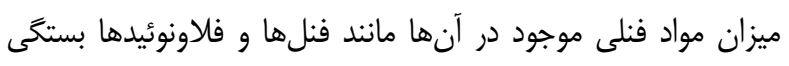
دارد كه با افزايش اين تركيبات در كياه خاصيت آنتى اكسيدانى نيز

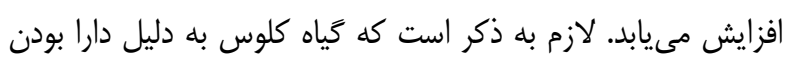

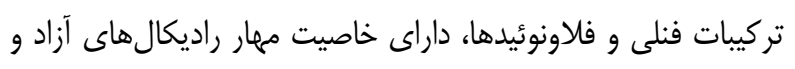

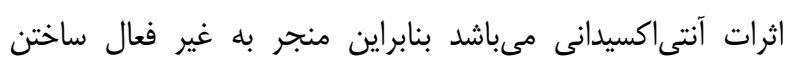

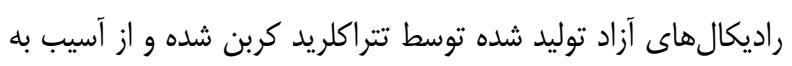

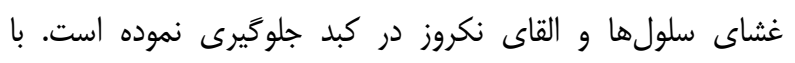




$$
\begin{aligned}
& \text { سرمى كلسترول و ترى كليسريدها شده و از كبد هرب جلوگيرى }
\end{aligned}
$$

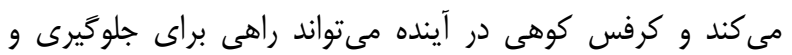

$$
\begin{aligned}
& \text { يبشرفت كبد קرب باشد. } \\
& \text { قدردانى را مىنمايند. }
\end{aligned}
$$

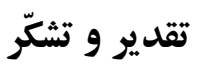

\section{تضاد منافع}

نويسندكان مقاله اعلام مى دارند كه هيج كَونه تضاد منافعى در

$$
\text { يزوهش حاضر وجود ندارد. }
$$

رنغ آميزى معمولى هماتوكسيلين ائوزين استفاده شد، نشان داد كه

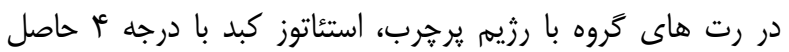

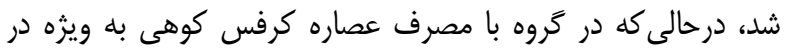

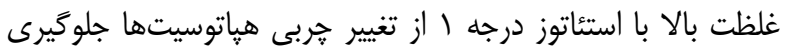

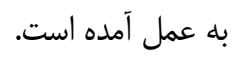

\section{نتيجه Fيرى}

با توجه به تحقيق حاضر كه بر روى بيان زن PNPLA3 با

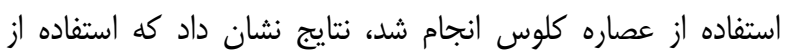

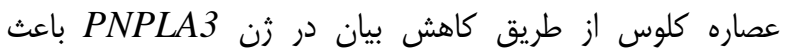

كاهش بيان زن موثر در سنتز لييبدها در كبد مى كَردد. همجنين

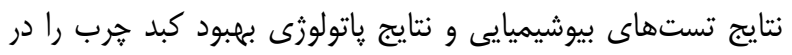

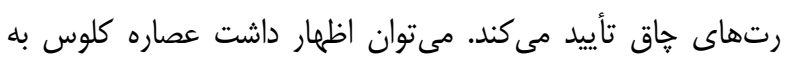

دليل داشتن فلاونوييدها مانند روتين و فتاليد باعث كاهش سط سطح

1- Vernon G, Baranova A, Younossi Z. Systematic review: the epidemiology and natural history of non-alcoholic fatty liver disease and non-alcoholic steatohepatitis in adults. Aliment Pharmacol Ther. 2011; 34(3): 274-85. DOI: $10.1111 / j .1365-2036.2011 .04724 . x$

2- Lamprecht A. Nanomedicines in gastroenterology and hepatology. Nat Rev Gastroenterol Hepatol. 2015; 12(4): 195204. DOI: $10.1038 /$ nrgastro.2015.37

3- Fleischman MW, Budoff M, Zeb I, Li D, Foster T. NAFLD prevalence differs among hispanic subgroups: the MultiEthnic Study of Atherosclerosis. World J Gastroenterol. 2014; 20(17): 4987-93. DOI: 10.3748/wjg.v20.i17.4987

4- Eslam M, George J. Genetic contributions to NAFLD: leveraging shared genetics to uncover systems biology. Nat Rev Gastroenterol Hepatol. 2020; 17(1): 40-52. DOI: 10.1038/s41575-019-0212-0

5- Kolodziejczyk AA, Zheng D, Shibolet O, Elinav E. The role of the microbiome in NAFLD and NASH. EMBO Mol Med. 2019; 11(2): e9302. DOI: 10.15252/emmm.201809302

6- Athyros VG, Alexandrides TK, Bilianou H, Cholongitas E, Doumas M, Ganotakis ES, et al. The use of statins alone, or in combination with pioglitazone and other drugs, for the treatment of non-alcoholic fatty liver disease/nonalcoholic steatohepatitis and related cardiovascular risk. An Expert Panel Statement. Metabolism. 2017; 71: 17-32. DOI: $10.1016 /$ j.metabol.2017.02.014

7- Friedman SL, Neuschwander-Tetri BA, Rinella M, Sanyal AJ. Mechanisms of NAFLD development and therapeutic strategies. Nat Med. 2018; 24(7): 908-22. DOI: 10.1038/s41591-018-0104-9

8- Sumida Y, Yoneda M. Current and future pharmacological therapies for NAFLD/NASH. J Gastroenterol. 2018; 53(3): 362-76. DOI: 10.1007/s00535-017-1415-1

9- Younossi Z, Anstee QM, Marietti M, Hardy T, Henry L, Eslam M, et al. Global burden of NAFLD and NASH: trends, predictions, risk factors and prevention. Nat Rev Gastroenterol Hepatol. 2018; 15(1): 11-20. DOI: $10.1038 /$ nrgastro.2017.109 
10- Lindén D, Ahnmark A, Pingitore P, Ciociola E, Ahlstedt I, Andréasson A-C, et al. Pnpla3 silencing with antisense oligonucleotides ameliorates nonalcoholic steatohepatitis and fibrosis in Pnpla3 I148M knock-in mice. Mol Metab. 2019; 22: 49-61. DOI: 10.1016/j.molmet.2019.01.013

11- Pingitore P, Dongiovanni P, Motta BM, Meroni M, Lepore SM, Mancina RM, et al. PNPLA3 overexpression results in reduction of proteins predisposing to fibrosis. Hum Mol Genet. 2016; 25(23): 5212-22. DOI: $10.1093 / \mathrm{hmg} / \mathrm{ddw} 341$

12- Yang J, Trépo E, Nahon P, Cao Q, Moreno C, Letouzé E, et al. PNPLA3 and TM6SF2 variants as risk factors of hepatocellular carcinoma across various etiologies and severity of underlying liver diseases. Int J Cancer. 2019; 144(3): 533-44. DOI: 10.1002/ijc.31910

13- Wang Y, Kory N, BasuRay S, Cohen JC, Hobbs HH. PNPLA3, CGI-58, and inhibition of hepatic triglyceride hydrolysis in mice. Hepatology. 2019; 69(6): 2427-41. DOI: 10.1002/hep.30583

14- BasuRay S, Wang Y, Smagris E, Cohen JC, Hobbs HH. Accumulation of PNPLA3 on lipid droplets is the basis of associated hepatic steatosis. Proc Natl Acad Sci U S A. 2019; 116(19): 9521-6. DOI: 10.1073/pnas.1901974116

15- Tabatabaeian J, Kadkhodaie A. The effect of dormancy breaking treatments on seed germination of Kelussia odoratissima Mozaff (kohrang). Iran J Seed Science Technology. 2019; 8(1): 201-12. [Persian] DOI: 10.22034/IJSST.2018.116895.1156

16- Kurhe Y, Radhakrishnan M, Gupta D. Ondansetron attenuates depression co-morbid with obesity in obese mice subjected to chronic unpredictable mild stress; an approach using behavioral battery tests. Metab Brain Dis. 2014; 29(3): 701-10. DOI: 10.1007/s11011-014-9574-8

17- Zarghani SS, Soraya H, Zarei L, Alizadeh M. Comparison of three different diet-induced non alcoholic fatty liver disease protocols in rats: A pilot study. Res Pharm Sci. 2016; 22(1): 9-15. DOI: 10.15171/PS.2016.03

18- Sazegar H, Balali E, Sadeghi Samani F. Effects of Kelussia odoratissima Mozaff Hydroalcoholic Extract on Liver Injury Induced by Carbon Tetrachloride in Mice. J Ilam Univ Med Sci. 2019; 26(5): 30-41. DOI: 10.29252/sjimu.26.5.30

19- Rychlik W. PCR primer design. Methods Mol Biol. 2007; 402: 35-59. DOI: 10.1007/978-1-59745-528-2_2

20- Rahimi Z, Salehi M, Dousti A. CCL2 Polymorphism in Drug-Resistant and Drug-Responsive Patients with Epilepsy in Isfahan, Iran. Med Lab J. 2017; 11(3): 30-4. DOI: 10.18869/acadpub.mlj.11.3.30

21- Fathiazad F, Ahmadi-Ashtiani H, Rezazadeh S, Jamshidi M, Mazandarani M, Khaki A. Study on phenolics and antioxidant activity of some selected plant of Mazandaran Province. J Med Plants. 2010; 9(34): 177-82. DOI: 20.1001.1.2717204.2010.9.34.19.7

22- Ghasemi Pirbalouti A, Shahvali A, Saghaee F, Azizi S, Hamedi B, Shahgholian L. Effect of Cichorium intybus L. extracts and Kelussia oderatassima Mozaff. essential oil on toxic of organophosphouros insecticides in RAT. Journal of Medicinal Herbs, "J. Med Herb" (Formerly known as Journal of Herbal Drugs or J. Herb Drug), 2010; 1(2): 30-35. Link

23- Romeo S, Kozlitina J, Xing C, Pertsemlidis A, Cox D, Pennacchio LA, et al. Genetic variation in PNPLA3 confers susceptibility to nonalcoholic fatty liver disease. Nat Genet. 2008; 40(12): 1461-5. DOI: 10.1038/ng.257

24- Stickel F, Buch S, Lau K, zu Schwabedissen HM, Berg T, Ridinger M, et al. Genetic variation in the PNPLA3 gene is associated with alcoholic liver injury in caucasians. Hepatology. 2011; 53(1): 86-95. DOI: 10.1002/hep.24017

25- Hoekstra M, Li Z, Kruijt JK, Van Eck M, Van Berkel TJ, Kuiper J. The expression level of non-alcoholic fatty liver disease-related gene PNPLA3 in hepatocytes is highly influenced by hepatic lipid status. J Hepatol. 2010; 52(2): 244-51. DOI: 10.1016/j.jhep.2009.11.004

26- Bruschi FV, Tardelli M, Claudel T, Trauner M. PNPLA3 expression and its impact on the liver: current perspectives. Hepatic medicine: evidence and research. 2017; 9: 55-66. DOI: 10.2147/HMER.S125718

27- Bruschi FV, Tardelli M, Herac M, Claudel T, Trauner M. Metabolic regulation of hepatic PNPLA3 expression and severity of liver fibrosis in patients with NASH. Liver Int. 2020; 40(5): 1098-110. DOI: 10.1111/liv.14402 